\title{
Prevalence of bovine trypanosomosis and assess- ment of knowledge and practices of livestock owners in the control of Trypanosomosis in Assosa District of Benishangul Gumuz Regional State, Ethiopia
}

\author{
Fantahun Miteku ${ }^{1 *}$, Wagari Tafese ${ }^{1}$ and Tsegaw Fentie ${ }^{2}$ \\ ${ }^{1}$ Veterinary Drugs and Animal Feed Administration and Control Authority, Addis Ababa \\ ${ }^{2}$ College of Veterinary Medicine and Animal Science, University of Gondar, Gondar, Ethiopia. \\ Corresponding author; Fantahun Miteku email: jarrafantahun@gmail.com
}

\begin{abstract}
A cross-sectional study was conducted from December 2013 to February 2014 to estimate the prevalence of bovine trypanosomosis and identify species of trypanosomes infecting cattle. Besides, attempt was made to assess the knowledge and practice of the livestock owners in Assosa district of Benishangul Gumuz Regional State, Ethiopia. A total of 310 blood samples were collected from randomly selected cattle. Packed cell volume (PCV) was measured and samples were examined for the presence of trypanosomes using the buffy coat technique. In this study bovine trypanosomes were detected in $22.9 \%$ of the blood samples. The most common trypanosome species identified were $T$. congolense $13.2 \%$ (41/310) followed by T. brucei $3.2 \%$ (10/310), T. vivax $2.9 \%$ (9/310), mixed infections of T. vivax and T. congolense 1.6\% (5/310), T. congolense and T. brucei $1.29 \%$ (4/310) and T. brucei and T. vivax $0.64(2 / 310)$. There were no statistically significant prevalence differences $(p>0.05)$ between sexes, ages category and management systems. However, prevalence difference was noted between poor and good body condition categories $(p<0.05)$. Animals with poor body condition were found 2.11 times more likely of getting trypanosome infection $(\mathrm{OR}=2.11,95 \% \mathrm{CI}, \mathrm{p}=0.027)$ than animals in good body condition. The mean PCV values recorded were $23.3 \%$ in parasitaemic and $25.1 \%$ in aparasitaemic animals with a statistically significant difference $(p<0.05)$. A questionnaire survey was conducted for the assessment of knowledge of farmers on control and prevention of bovine trypanosomosis provided important information on farmer's knowledge of bovine trypanosomosis and practices in control and prevention measures. In this study few livestock owners know the vector (tsetse) association with the disease. In conclusion, this study confirmed that trypanosomes are still a threat to cattle in the study area. Therefore, it is
\end{abstract}


recommended that an integrated prevention and control program have to be designed and implemented to minimize their impacts on livestock production.

Keywords: Assosa; Cattle; Knowledge assessment; Trypanosomosis; Practices, Prevalence

\section{Introduction}

Livestock is a significant contributor to economic and social development in Ethiopia at the household and national level. On a national level, livestock contributes a significant amount to export earnings in the formal market ( $10 \%$ of all formal export earnings or $\$ 150 \mathrm{~m}$ annually) and the informal market (likely $\$ 300 \mathrm{~m}+$ annually). Livestock accounts for $15-17 \%$ of total GDP and 35$49 \%$ of agricultural GDP. Livestock directly contributes to the livelihoods of more than $70 \%$ of Ethiopians. Ethiopia has the largest livestock herd in subSaharan Africa, with an estimated cattle population of 49 million, sheep population of 25 million and goat population of nearly 22 million (EATA, 2014).

Tsetse transmitted animal trypanosomosis still remains as one of the largest causes of livestock production losses in Ethiopia. About 10 to $15 \%$ of the land believed to be suitable for livestock production is affected by one or two species of the tsetse flies. While tsetse-borne trypanosomosis is excluding agriculturally suitable land of the country; 14 million head of cattle are at the risk of contracting trypanosomosis at any one time (Desta et al, 2013).

According to Abebe (2005), trypanosomosis is prevalent in two main regions of Ethiopia that is, the Northwest and the Southwest regions. Six species of trypanosomes are recorded in Ethiopia and the most important trypanosomes, in terms of economic loss in domestic livestock are the tsetse transmitted species: T. congolense, T. vivax and T. brucei. For the closely related T. brucei subspecies, T. b. rhodensiense, which causes human sleeping sickness, cattle can be a reservoir host. The other trypanosome species of economic importance are T. evansi of camels and T. equiperdum of horses (Abebe, 2005). Recent findings and field observations have indicated that the common trypanosomosis control tools; i.e., trypanocurative and trypanoprophylactic drugs have become ineffective in many areas due to development of drug resistance by the parasite. Moreover, toxicity of the drugs and exhibition of antigenic variation which hampers vaccine production are the limitations facing the modern vet- 
erinary medicine (Uilenberg, 1998). Though trypanosomosis is a problem for cattle production in the study area, information is limited to the magnitude of the disease and farmers' perception on the presence, impact and management of trypanosomosis in cattle, and their desire for establishment of intervention programs against the disease Thus, the objectives of this study were to estimate the prevalence of bovine trypanosomosis and associated risk factors in the district; and to assess the knowledge and practices of livestock owners towards the control of bovine trypanosomosis.

\section{Materials and methods}

\section{Description of study area and population}

The study was conducted from December 2013 to February 2014 in Assosa Zone of Benishangul Gumuz Regional State (Figure 1). The area stretches over $2313 \mathrm{~km}^{2}$ in a major tsetse and tsetse born trypanosomosis belt characterized by lowland plane with altitude range of 580-1544 meter above sea level. Assosa is located between $8^{\circ} 30^{\prime \prime}$ and $40^{\circ} 27^{\prime \prime} \mathrm{N}$ and $34^{\circ} 21^{\prime \prime}$ and $39^{\circ} 1$ " E. According to National Meteorological Service, the average annual rainfall is $1316 \mathrm{~mm}$ with uni-modal type of rainfall that occurs between April and October. Its mean annual temperature ranges between $16.75^{\circ} \mathrm{C}$ and $27.9^{\circ} \mathrm{C}$. Assosa zone has $35.6 \%$ of the livestock population of the region constituting 81,939 cattle, 73,181 goats 10,231 sheep, 14,089 donkeys, 40, 3153 poultry, 29 horses and 59,695 beehives (CSA, 2005). The study was carried out on indigenous zebu cattle of all age groups of both sexes in five selected kebeles in and around Assosa town which are managed mostly under extensive and semi-intensive production systems. 


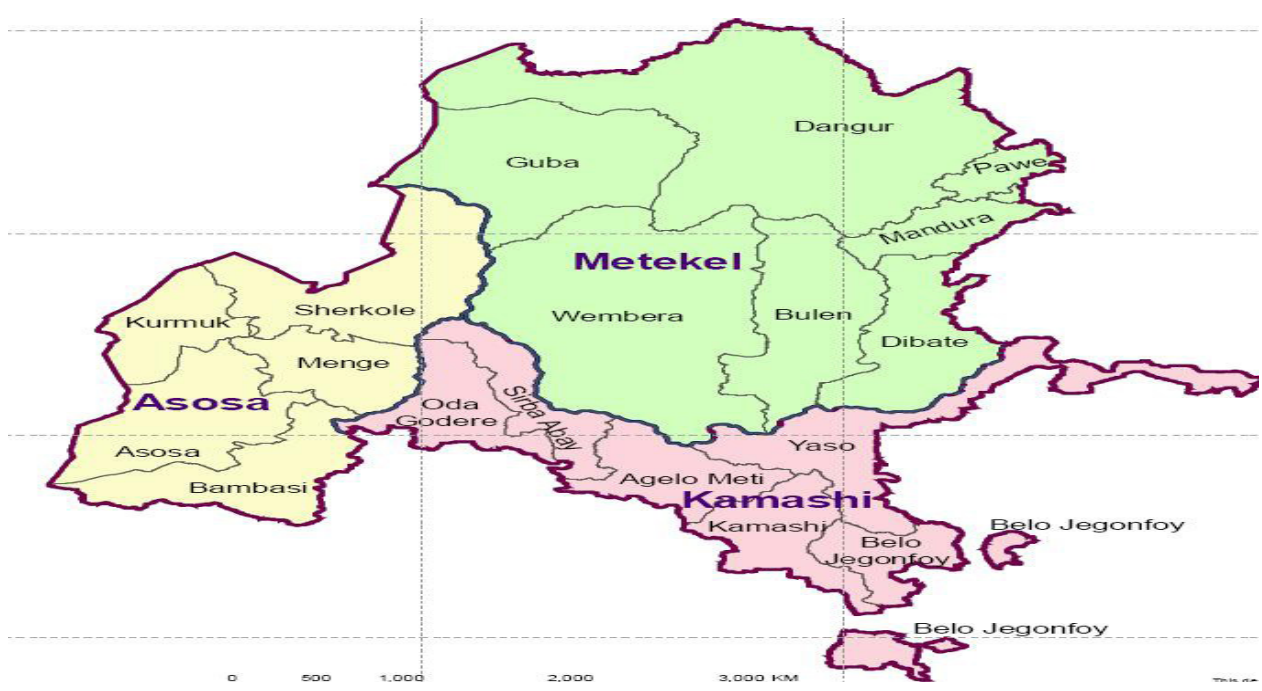

Figure 1: Map of study area, Assosa district in Benishangul Gumuz Regional State

Source: From Wikipedia, the free encyclopedia

\section{Study design}

A cross-sectional study was conducted from December 2013 to February 2014 in five peasant associations (amba-1, amba-5, amba-14, Abrahamo, AAGRC), and Assosa town. During sampling sex, age, body condition, breed, management system and origin of animals were recorded. The body condition score was categorized as poor and good taking the middle point as a border in the 9 scale scores of method of body condition scoring for zebu cattle (Nicholson and Butterworth, 1986).

\section{Questionnaire survey}

Questionnaire survey was conducted to assess the knowledge and practices of farmers in the control of trypanosomiasis. To address the questionnaire survey, a total of 70 farmers in the 5 districts were interviewed with a structured questionnaire format. The interviewed people were selected randomly from the study areas. 


\section{Sample Size Determination and Sampling Method}

The desired sampling size was calculated according to the formula given by Thrusfield (2005), with 28.1\% excepted prevalence (Mulaw et al., 2010), at 95\% confidence interval and 5\% absolute precision. Accordingly, a total of 310 samples were collected during the study period using systematic random sampling technique. Sample size was proportionally distributed to kebeles.

\section{Parasitological study}

Packed Cell Volume (PCV) determination: Blood samples were obtained by puncturing the marginal ear vein with a lancet and collected directly into a pair of heparinized capillary tubes. The tubes were then sealed at one end with crystal seal. The capillary tubes were placed in micro-hematocrit centrifuge and were allowed to centrifuge at 12,000 revolutions per minute (rpm) for 5 minutes. After centrifugation, the capillary tubes were placed in a hematocrit reader. The length of the packed red blood cells column is expressed as a percentage of the total volume of blood. Animals with PCV less than 24\% were considered to be anaemic (Murray, 1988).

Buffy Coat Technique: After the centrifugation, trypanosomes were usually found in or just above the buffy coat layer. The capillary tube was cut using a diamond tipped pen $1 \mathrm{~mm}$ below the buffy coat to include the upper most layers of the red blood cells and $3 \mathrm{~mm}$ above to include the plasma. The content of the capillary tube was expressed onto a glass slide, and covered with cover slip. The slide was examined under $\mathrm{x} 40$ objective and x10 eye piece for movement of parasite. Trypanosome species were identified according to their morphological descriptions on Giemsa stained blood film as well as movement in wet film preparations (Marquardt et al., 2000).

\section{Data Management and Analysis}

The data collected was entered into Microsoft Excel spread sheet. All analysis was performed using STATA statistical software package (Stata 11.0). P-value $<0.05$ was considered to determine level of significance. 


\section{Result}

\section{Parasitological prevalence}

Out of 310 blood samples, the overall prevalence of bovine trypanosomosis was found to be $22.9 \%$ (Table 1 ).

Table 1: Prevalence of bovine trypanosome infections in Assosa district on the basis of kebele/location.

\begin{tabular}{lccc}
\hline Kebele & $\begin{array}{l}\text { No of animals } \\
\text { examined }\end{array}$ & No. positive & \multicolumn{2}{c}{$\begin{array}{l}\text { Prevalence } \\
\text { (\%) }\end{array}$} \\
\hline AAGRC & 20 & 1 & 5 \\
Assosa & 110 & 27 & 24.5 \\
Amba-14 & 54 & 8 & 14.8 \\
Abrahamo & 18 & 7 & 38.8 \\
Amba-5 & 54 & 14 & 25.9 \\
Amba-1 & 54 & 14 & 25.9 \\
Total & 310 & 71 & 22.9 \\
\hline
\end{tabular}

The most common trypanosome species identified were $T$. congolense $13.2 \%$ (41/310) followed by $T$. brucei $3.2 \%$ (10/310), T. vivax $2.9 \%$ (9/310), mixed infections of T. vivax and T. congolense 1.6\% (5/310), T. congolense and T. brucei $1.29 \%$ (4/310) and T. brucei and T. vivax 0.64 (2/310) (Table 2).

Table 2: Prevalence of bovine trypanosome in Assosa district on the basis of Trypanosoma by species identified.

\begin{tabular}{|c|c|c|c|c|c|c|c|}
\hline \multirow{3}{*}{ Kebele } & \multirow{3}{*}{$\begin{array}{l}\text { Positive } \\
\text { (\%) }\end{array}$} & \multicolumn{6}{|c|}{ Trypanosoma identified } \\
\hline & & \multirow{2}{*}{$\begin{array}{l}\text { T. } \\
\text { congolense }\end{array}$} & \multirow{2}{*}{$\begin{array}{l}\text { T. } \\
\text { brucei }\end{array}$} & \multirow{2}{*}{$\begin{array}{l}\text { T. } \\
\text { vivax }\end{array}$} & \multicolumn{3}{|c|}{ Mixed infections } \\
\hline & & & & & $\begin{array}{l}\text { T. } \\
\text { congolense } \\
\text { and } \\
\text { T. vivax }\end{array}$ & $\begin{array}{l}\text { T. } \\
\text { congolense } \\
\text { and } \\
\text { T. brucei }\end{array}$ & $\begin{array}{l}\text { T. brucei } \\
\text { and } \\
\text { T. vivax }\end{array}$ \\
\hline AAGRC & $1(5 \%)$ & $1(5 \%)$ & 0.00 & 0.00 & 0.00 & 0.00 & 0.00 \\
\hline Assosa & $27(24.5 \%)$ & $20(18.2 \%)$ & $4(3.6 \%)$ & $2(1.8 \%)$ & $2(1.8 \%)$ & $1(0.9 \%)$ & 0.00 \\
\hline Amba-14 & $8(14.8 \%)$ & $3(5.5 \%)$ & $1(1.8 \%)$ & $1(1.8 \%)$ & $1(1.8 \%)$ & $1(1.8 \%)$ & $1(1.8 \%)$ \\
\hline Abrahamo & $7(38.8 \%)$ & 6(33.3) & $1(5.5 \%)$ & 0.00 & 0.00 & 0.00 & 0.00 \\
\hline Amba-5 & $14(25.9)$ & $7(12.9 \%)$ & $2(3.7 \%)$ & $2(3.7 \%)$ & $1(1.8 \%)$ & $2(3.7 \%)$ & 0.00 \\
\hline Amba-1 & $14(25.9)$ & $4(7.4 \%)$ & $2(3.7 \%)$ & $4(7.4 \%)$ & $1(1.8 \%)$ & 0.00 & $1(1.8 \%)$ \\
\hline Total & $71(22.9 \%)$ & $41(13.2 \%)$ & $10(3.2 \%)$ & $9(2.9 \%)$ & $5(1.6 \%)$ & $4(1.29 \%)$ & $2(0.6 \%)$ \\
\hline
\end{tabular}


Among host and management related factors only body condition was found to be risk factor for trypanosome infection. Animals of poor body condition were 2.11 times more likely of getting trypanosome infection than animals in good body condition (Table 3).

Table 3: Host and management-related risk factors associated with the prevalence of trypanosome infections.

\begin{tabular}{|c|c|c|c|c|c|c|}
\hline Risk Factor & & $\begin{array}{l}\text { No of } \\
\text { examined }\end{array}$ & $\begin{array}{l}\text { Prevalence } \\
\text { (\%) }\end{array}$ & Odds ratio & $95 \%$ CI & p-value \\
\hline \multirow{2}{*}{$\begin{array}{l}\text { Body } \\
\text { condition }\end{array}$} & Good & 261 & $54(20.7 \%)$ & 1.00 & - & \\
\hline & Poor & 49 & $17(35.4 \%)$ & 2.11 & $\begin{array}{l}1.09- \\
4.09\end{array}$ & 0.027 \\
\hline \multirow[t]{2}{*}{ Sex } & Female & 180 & $38(21.1 \%)$ & 1.00 & - & 0.54 \\
\hline & Male & 130 & $33(25.4 \%)$ & 1.18 & $\begin{array}{l}0.69- \\
2.01\end{array}$ & \\
\hline \multirow[t]{3}{*}{ Age } & $<2$ yrs & 40 & $13(32.5 \%)$ & 1.00 & - & 0.131 \\
\hline & $2-4$ yrs. & 144 & $31(10 \%)$ & 0.56 & $\begin{array}{c}0.26- \\
1.19\end{array}$ & \multirow{2}{*}{0.300} \\
\hline & $>4$ yrs. & 126 & $25(8 \%)$ & 0.43 & $\begin{array}{l}0.19- \\
0.94\end{array}$ & \\
\hline \multirow[t]{2}{*}{$\begin{array}{l}\text { Management } \\
\text { system }\end{array}$} & $\begin{array}{l}\text { Semi- } \\
\text { intensive }\end{array}$ & 20 & $1(5 \%)$ & 1.00 & - & \multirow[b]{2}{*}{0.082} \\
\hline & Extensive & 290 & $70(24.1 \%)$ & 6.05 & $\begin{array}{l}0.79- \\
45.97\end{array}$ & \\
\hline
\end{tabular}

The mean PCV values and standard deviation (SD) for the whole examined animals was $25.03 \pm 5.5$. However, the mean PCV value for aparasitaemic (nondiseased) animals was $25.8 \pm 5.5$ and mean PCV of Parasitaemic (diseased) animals were $22.3 \pm 4.4$ (Table 4 ). The difference was found to be statistically significant $(\mathrm{p}<0.001)$.

Table 4: Mean Packed Cell Volume in parasitaemic and aparasitaemic animals.

\begin{tabular}{lccc}
\hline Status & $\begin{array}{l}\text { Sample } \\
\text { frequency }\end{array}$ & $\begin{array}{l}\text { Mean PCV } \\
\mathbf{( \% )}\end{array}$ & SD \\
\hline Parasitaemic & 71 & 22.3 & 4.4 \\
Aparasitaemic & 239 & 25.8 & 5.5 \\
Total & $\mathbf{3 1 0}$ & $\mathbf{2 5 . 0 3}$ & $\mathbf{5 . 5}$ \\
\hline
\end{tabular}

Ethiop. Vet. J., 2019, 23 (2), 64-76 


\section{Questionnaire Survey}

All interviewed livestock owners (100\%) know bovine trypanosomosis very well and locally call it "Wozwuz" or Gendi to say disease that causes wasting or emaciation. According to farmers response to the major diseases symptoms in relation to trypanosomosis, the following symptoms were listed according to their frequency of response; emaciation, weakness, rough hair coat, reduced milk production, depression, lacrimation and nasal discharge (Table 5).

According to farmers response the major signs in relation to trypanosomosis were recorded. According to farmer's frequency of response: rough hair coat, weakness, depression, reduced milk production, emaciation, lacrimation and nasal discharge were the major clinical signs. Concerning knowledge of disease transmission and season of occurrence, only $12.8 \%$ of the farmers responded that the tsetse flies are responsible, while $63 \%$ associates with cold weather and $24.2 \%$ do not know anything about the vector for trypanosomosis. The respondents consider season of occurrence of the disease to be from June to September (34.3\%), July to December (25.7\%) and September to November (40\%) (Table 5). 
Table 5: Findings of the questionnaire survey

\begin{tabular}{|c|c|c|c|c|}
\hline No & Variables & & $\begin{array}{l}\text { Frequency of } \\
\text { Response }\end{array}$ & Percentage (\%) \\
\hline \multirow[t]{10}{*}{1} & \multirow{7}{*}{$\begin{array}{l}\text { Diseases symptoms in relation } \\
\text { to trypanosomosis }\end{array}$} & Emaciation & 70 & 100 \\
\hline & & Weakness & 58 & 82.8 \\
\hline & & Rough hair coat & 45 & 64.3 \\
\hline & & $\begin{array}{l}\text { Reduced milk } \\
\text { production }\end{array}$ & 38 & 54.3 \\
\hline & & Depression & 26 & 37.1 \\
\hline & & Lacrimation & 24 & 34.3 \\
\hline & & Nasal discharge & 17 & 24.3 \\
\hline & \multirow[t]{3}{*}{ Disease transmission } & Tsetse flies & 9 & 12.8 \\
\hline & & Cold weather & 44 & 63 \\
\hline & & Don't know & 17 & 24.2 \\
\hline \multirow[t]{3}{*}{2} & \multirow[t]{3}{*}{ Season of occurrence } & $\begin{array}{l}\text { June to } \\
\text { September }\end{array}$ & 24 & 34.3 \\
\hline & & $\begin{array}{l}\text { September to } \\
\text { November }\end{array}$ & 28 & 40 \\
\hline & & July to December & 18 & 25.7 \\
\hline \multirow[t]{2}{*}{3} & \multirow[t]{2}{*}{ Control and prevention } & $\begin{array}{l}\text { Trypanocidal } \\
\text { drugs }\end{array}$ & 70 & $100 \%$ \\
\hline & & Nothing & - & - \\
\hline
\end{tabular}

\section{Discussion}

The study revealed that the trypanosomosis caused by different species of trypanosomes were common in Assosa district in domestic livestock's specially cattle's. The overall disease prevalence in the study area was $22.9 \%$ indicating that trypanosomes are still of much concern and represent a major obstacle to livestock production. This study agreed with findings of $28.1 \%$ (Mulaw et al., 2010) in Assosa district, 24.7\% (Ali and Bitew, 2011) in Mao Komo special district which were higher than the current study. The current result was relatively lower than the previous findings. This could be due to variation in study site, sample size, study season, extensive or seasonal clearing of bushes, expansion of human and agricultural investment in the area affecting the agro-ecology.

This study has also shown that $T$. congolense was the dominant species with a proportion of $13.2 \%$ followed by $T$. brucei $3.2 \%$, T. vivax $2.9 \%$, mixed infections 
(T. congolense and T. vivax $1.6 \%, T$. congolense and T. brucei $1.29 \%, T$. vivax and T. brucei $0.6 \%$ ). This result concords with the reported proportion of $63.2 \%$ T. congolense, $13.6 \%$ T. vivax, $11.6 \%$ T. brucei and $11.6 \%$ mixed infection in cattle from the neighboring Mao-Komo special district (Ali and Bitew, 2011). This result is also in agreement with the reported proportions of $T$. congolense (77.6\%) followed by T. vivax (14.9\%), T. brucei (6.0\%) and T. congolense and T. vivax mixed infection (1.5\%) from Metekel and Awi zones (Afework et al., 2000). The high ratio of $T$. congolense in tsetse-infested area may be ascribed to the more efficient transmission of $T$. congolense by major cyclical vectors than T. vivax in East Africa (Kuzoe, 1991). The difference in the infection rate may be explained by the variation in study site and duration, season of study and vegetation coverage. The highest and the lowest prevalence were recorded in Abrahamo (38\%) and AAGRC (5\%) respectively. However, there was no statistically significant difference ( $>>0.05)$ in the prevalence of trypanosomosis in the study sites, because they were located in similar agro-ecology of tsetse belt. The associations of the disease with age and sex were assessed. No statistically significant association was observed with respect to age and sex ( $>>0.05)$. Infection in poor body condition was significantly higher than good body conditions. This is finding is in agreement with a study report by Mehirt and Mamo, (2007). Out of infected animals examined $20.7 \%$ from good body condition and $35.4 \%$ from poor body condition were found positive of the trypanosomosis and they were statistically significant $(\mathrm{p}<0.05)$. This is in agreement with Afework et al., 2000. The mean PCV of parasitaemic animals is lower than mean PCV of aparasitaemic animals and, the difference was highly significant $(p<0.001)$. This finding roughly in agreement with what was reported by Cherinet et al. (2004), Tadesse et al. (2011) and Zeryehun and Abraham (2012).

In order to control and prevent bovine trypanosomosis, knowledge of farmers should be assessed. Rapid method for assessing their knowledge and enhancing the control and prevention with active participation of livestock owners should be in place. Therefore, this survey was conducted with the objective of exploring the knowledge assessment of farmers in control and prevention of bovine trypanosomosis in Assosa district. According to farmers response, the season of occurrence of the disease considered to be June to September 24 (34.3\%), July to December 18 (25.7\%) and September to November 28 (40\%).

Ability of livestock keepers to determine seasonal variations and peak level of trypanosomosis and its vectors as recorded in the present study is in line with 
the reports of Chernet et al. (2004); Dagnachew et al. (2005) and Tesfaye et al. (2001) from Ethiopia, Catley et al. (2009) from Kenya and Grace et al. (2009) from west Africa. Wet and warm months of the year (such as May and June) are favorable periods for vectors and trypanosomes growth and multiplication and are observed as peak months of infection). The way of transmission of trypanosomosis is not well known by most of farmers and they have no idea (24.2\%), while some consider as to be following cold season (63\%). However, a few knows as by tsetse flies (12.8\%). This finding disagreed with recent reports showing significantly higher numbers of respondents in the study districts are aware of the causal association between biting flies and bovine trypanosomosis but not considered as the etiological factor. This coupled with their knowledge on the signs of the disease and treatment suggests that the farmers have comparable understanding of the problem as reported earlier (Maudlin et al., 2004; Catley et al., 2009) in other African countries.

In conclusion, animal trypanosomosis is a major obstacle to livestock production and productivity in Assosa district. In this study only few livestock owners know the vector (tsetse) association with the disease. However, most of them have satisfactory knowledge in suggesting signs of trypanosomosis and its impact on production and they have strong desire to give their part on control and prevention of trypanosomosis. The prevalence of trypanosomosis found in the study area is high. Thus, further studies on the distribution of tsetse flies and trypanosomosis should be conducted throughout all seasons of the year. Awareness creation on vector (tsetse) control by the farmers by providing trainings and materials for trapping is very crucial.

\section{References}

Afework, Y., Clausen, P.H., Abebe G, Tilahun, G., Mehlitz, D., 2000. Multiple-drug resistant Trypanosome congolense populations in village cattle of metekel district, north-west Ethiopia. Acta Trop., 76(3), 231-238.

Ali, D. and M. Bitew, 2011. Epidemiological study of bovine trypanosomosis in Mao-Komo special district, Benishangul Gumuz, Regional State, Western Ethiopia. Global Veterinaria, 6(4), 402-408.

Catley A, Irungu P, Simiyu K, Dadye J, Mwakio W, Kirangu J, Nyamwaro SO.,2009. Participatory investigations of bovine trypanosomosis in Tana River district, Kenya. Med. Vet. Entomol., 16 (1), 55-66

Chernet T, Sani RA, Panandam JM, Nadzr S, Speybroeck N, Van den Bossche P., 2004. Seasonal prevalence of bovine trypanosomosis in a tsetse-infested zone and 
a tsetse-free zone of the Amhara Region, Northwest Ethiopia. Onderstepoort J. Vet. Res., 71, 307-312.

CSA (Central Statistical Authority), 2005. Agricultural Sample Survey, Statistical Bulletin331, Addis Ababa, Ethiopia, 85, 391-404.

CSA (Central Statistical Authority), 2008. Federal Democratic Republic of Ethiopia, Central Statistical Agency, Agricultural Sample Survey, Statistical Bulletin 417, Addis Ababa, Ethiopia, pp 44.

Dagnachew, S., A.K. Sangwan and Abebe, G., 2005. Epidemiology of bovine trypanosomosis in the Abay (Blue Nile) basin areas of northwest Ethiopia. Rev. Med. Vet., 58(3):151-157.

Desta, M., Menkir, S., Kebede, A., 2013. The study on tsetse fly (Glossina species) and their role in the trypanosome infection rate in Birbir valley, Baro Akobo River system, western Ethiopia. J. Vet. Med. Anim. Health. 5(7), 186-194.

ETTA (Ethiopia Agricultural Transformation Agency), 2014.

FAO, 1998. A field guide for the diagnosis, treatment and prevention of African Trypanosomes: In Food and Agriculture organization of the United Nations, Rome, Italy, Pp. 170.

Feysa, F., 2004. Current Epidemiology situation of bovine trypanosomiasis in limu shaye tsetse control areas of upper Didessa valley. MSc, Faculty of Veterinary Medicine, Addis Ababa University, Debre Zeit, Ethiopia.

Abebe, G., 2005. Trypanosomosis in Ethiopia. SINET Ethiopia J. Sci, 27(1), 1-8.

Grace, D., Randolph, T., Affognon, H., Dramane, D., Diall, O., Clausen, P.H., 2009. Characterization and validation of farmers' knowledge and practice of cattle trypanosomosis management in the cotton zone of West Africa. Acta. Trop., 111(2), 137-143.

Kuzoe, F.A.S., 1991. Perspectives in research and control of African trypanosomiasis. Ann.Trop. Med. Parasitol., 85(1), 33-41.

Maudlin I, Holmes PH, Miles MA., 2004. The Trypanosomiasis. CAB International Publishing, Wallingford, UK, pp. 1-634.

Mihret, A., and Mamo, G.,2007. Bovine Trypanosomosis in three districts of East Gojjam Zone bordering the Blue Nile River in Ethiopia. J. Infect. Dev. Ctries., 1(3), 321-325

Mulaw, S., Addis, M., Fromsa, A., 2010. Study on the Prevalence of Major Trypanosomes Affecting Bovine in Tsetse Infested Assosa District of Benishangul Gumuz Regional State, Western Ethiopia, Global Vet.,7 (4), 330-336.

Nicholson, M.J., and Butterworth, M.H., 1986. A Guide to Condition Scoring of Zebu Cattle. International Livestock Centre for Africa. Addis Ababa, Ethiopia, pp. 29. 
Murray, M., Dexter, T.M., 1988. Anemia in bovine Africa Trypanosomosis. Acta Trop., 45, 389-432.

Marquardt, W.C, Demaree, R.C., and Grieue, R. B., 2000, Parasitology and vector biology, $2^{\text {nd }}$ edn. Academic Press, London, UK.

Tadesse, A., Hadgu, E., Mekibib, B., Abebe, R., Mekuria, S., 2011. Mechanically Transmitted Bovine Trypanosomosis in Tselemty Woreda, Western Tigray, and Northern Ethiopia, J. Agri., 6(1),10-13.

Tesfaye, D, Speybroeck, N., Deken, R.D, Thys, E., 2001. Economic burden of bovine trypanosomosis in three villages of Metekel zone, Northwest, Ethiopia. Trop. Anim. Hlth, Prod., 44(4), 873-879.

Thrusfield, M., 2005. Veterinary Epidemiology. $3^{\text {rd }}$ ed., Blackwell Science Ltd, UK, pp. 233-250.

Torr, S.J., Wilson, P.J., Schofield, S., Mangwiro, T.N.C., Akber, S.,White, B.N., 2001. Application of DNA markers to identify the individual-specific host of tsetse feeding on cattle. Med. Vet. Entomol., 15(1),78-86.

Uilenberg G. (1998). A Field Guide for the Diagnosis, Treatment, and Prevention of African Animal Trypanosomosis. Food and Agriculture Organization of the United Nations (FAO), Rome, Italy. pp 170.

Urquhart, G.M., Armour, J., Duncan, J.L., Dunn, A.M., Jennings, F.W., 1996. Veterinary Parasitology, $2^{\text {nd }}$ ed. Blackwell, Science Ltd.

Wikipedia., 2005. The free encyclopedia.

Zeryehun, T., and Abraham, Z., 2012. Prevalence of Bovine Trypanosomosis in Selected District of Arba Minch, SNNPR, Southern Ethiopia. Global Vet., 8 (2),168-173. 